\title{
OPTIMALISASI PENERIMAAN REMUNERASI DOSEN MENGGUNAKAN METODE RULE BASE REASONING
}

\author{
Samsudin \\ Sistem Informasi, Universitas Islam Negeri Sumatera Utara Medan, Indonesia \\ Jl. IAIN No. 1 Medan 20235, Telp. (061) 6615683-6622925, Fax. (061) 6615683 \\ samsudin@uinsu.ac.id
}

\begin{abstract}
Remuneration is a term that relates to employee payroll which is set by certain regulations routinely based on work values, with the aim of creating better and cleaner governance and increasing motivation and work performance. Performance is determined by assessing the compilation oflecturer'swork files and then verified by the department that responsible to it. Rule Base Reasoning is an expert system based on a series of rules that represent human knowledge and experience in solving some complex cases. Expert system is a system whose capability to adopt human knowledge in solving problems so the system can solve problems as is usually done by experts. To implement this method a web-based system is used using the PHP programming language with the concept of Object Oriented Programming with ecpectation this system can be designed more easily and can be developed continuously so it can optimize the acceptance of lecturer remuneration andso far it can minimize the possibility of errors due to human errors. on institutions and lecturers.
\end{abstract}

Keywords: Remuneration, Rule Base Reasoning, Performance, Lecturers, Expert Systems.

\begin{abstract}
Abstrak
Remunerasi merupakan sebuah istilah yang berhubungan dengan penggajian pegawai yang ditetapkan dengan peraturan tertentu secara rutin berdasarkan nilai-nilai kerja, dengan tujuan terciptanya tata kelola yang lebih baik dan bersih serta meningkatkan motivasi dan prestasi kerja.Kinerja ditentukan dengan pengumpulan bukti kerja kepada pihak yang bertanggung jawab dan dihitung oleh badan yang ditentukan.Rule Base Reasoning adalah sistem pakar berdasarkan serangkaian aturan-aturan yang merupakan representasi dari pengetahuan dan pengalaman manusia dalam memecahkan kasus yang rumit. Sistem pakar adalah suatu sistem yang berusaha mengadopsi pengetahuan manusia dalam menyelesaikan masalah sehingga sistem tersebut dapat menyelesaikan masalah seperti yang biasa dilakukan oleh para pakar.Untuk mengimplementasikan metode ini dibuat sebuah sistem berbasis web menggunakan bahasa pemrograman PHP dengan konsep Object Oriented Programming dengan harapan sistem ini bisa dirancang lebih mudah dan bisa dikembangkan secara berkelanjutan dan dapat mengoptimalkan penerimaan remunerasi dosen sehingga bisa memperkecil kemungkinan terjadinya kesalahan karena human error yang bisa menyebabkan kerugian pada pihak institusi maupun dosen.
\end{abstract}

Kata kunci: Remunerasi, Rule Base Reasoning, Kinerja, Dosen, Sistem Pakar.

Optimalisasi Penerimaan Remunerasi Dosen dengan Metode Rule Base Reasoning (Samsudin)| 224 


\section{PENDAHULUAN}

\subsection{Latar Belakang}

Perkembangan Teknologi Informasi telah banyak mempengaruhi berbagai aspek kehidupan umat manusia dalam menjalankan aktivitas sehari-hari. Penggunaan komputer telah jauh mengalami kemajuan dari sekedar teknologi alat hitung hingga pengambilan keputusan. Komputer banyak dimanfaatkan dalam proses analisis, diagnosa dan sistem berbasis pengetahuan lainnnya.

Remunerasi merupakan sebuah istilah yang berhubungan dengan penggajian pegawai yang ditetapkan dengan peraturan tertentu secara rutin berdasarkan nilainilai kerja, dengan tujuan terciptanya tata kelola yang lebih baik dan bersih serta meningkat motivasi dan prestasi kerja. Kinerja ditentukan dengan pengumpulan bukti kerja kepada pihak bertanggung jawab dan dihitung oleh badan yang ditentukan. Rule Base Reasoning adalah sistem pakar berdasarkan serangkaian aturan-aturan yang merupakan representasi dari pengetahuan dan pengalaman manusia dalam memecahkan kasus yang rumit. Satu aturan direpresentasikan dengan: IF < kondisi>THEN<kesimpulan>, di mana setiap kondisi-kondisi dari aturan ke aturan yang lainnya terhubung satu dengan yang lain melalui penghubung logika seperti penghubung dan, atau, negasi, serta penghubung lainnya membentuk sebuah fungsi logis. Implementasi Rule Based Reasoning akan dilakukan saat pencocokan Beban Kerja Dosen yang telah dilakukan dengan rubrik yang disediakan oleh Universitas.

Aktivitas dosen tersebut akan di tersebut dicocokan dengan literatur berklausa IF, dan mendapatkan output binaryyang nantinya akan dilihat kecocokannya antara Rubrik lainnya. Metode ini dipandangkan mampu untuk memilih hasil yang cocok untuk penilai menentukan jumlah remunerasi yang akan diterima oleh seorang pegawai. Sedangkan pengambangan sistem menggunakan konsep Object Oriented berbasis web, Object Oriented adalah suatu metode pemrograman yang berorientasi kepada objek. Tujuan dari Object Oriented diciptakan adalah untuk mempermudah pengembangan program dengan cara mengikuti model yang telah ada di kehidupan sehari-hari. Dengan menggabungkan kedua konsep ini, proses pemberian remunerasi diharapkan berjalan baik dan terhindar dari salah perhitungan yang mengakibatkan kerugian pihak institusi maupun pegawai.

\subsection{Identifikasi Permasalahan}

a. Pada saat ini penilaian penerimaan remunerasi dosen biasa di UIN Sumatera Utara Medan berdasarkan kelebihan nilai Beban Kerja Dosen (BKD) yang dinilai oleh dua orang Asessor, yang terkadang penilaiannya tergantung dari objektivitas Asesor masing-masing.

b. Penginputan bukti Beban Kerja Dosen (BKD) oleh dosen masih belum terkomputerisasi dengan baik, karena masih offline menggunakan aplikasi Microsoft Office Access. 


\subsection{Perumusan Permasalahan}

Berdasarkan latar belakang di atas maka dapat dirumuskan permasalahan penelitian sebagai berikut:

a. Bagaimanakah penggunaan Rule Based Reasoning dapat digunakan dalam perancangan sistem penerimaan remunerasi dosen biasa UIN Sumatera Utara Medan?

b. Bagaimanakah konsep Object Oriented Programming dapat digunakan pada Sistem Pakar Rule Based Reasoning?

\subsection{Tujuan Penelitian}

Adapun tujuan dari penelitian ini adalah:

a. Mengetahui penggunaan Rule Based Reasoning dalam memecahkah masalah menggunakan basis Knowledge.

b. Merancang sistem penerimaan remunerasi dosen UIN Sumatera Utara Medan menggunakan metodologi Object Oriented Programming berbasis Web.

\section{METODOLOGI PENELITIAN}

Metodologi penelitian dan kerangka kerja penelitian yang digunakan dalam penyelesaian penelitian ini. Kerangka kerja ini merupakan langkah-langkah yang akan dilakukan dalam rangka penyelesaian masalah yang akan dibahas.

\subsection{Pengumpulan Data}

Pada tahapan ini akan dilakukan pengumpulan data yang menyangkut dengan sistem yang akan dibangun. Adapun cara atau metode yang bisa dilakukan dalam pengumpulan data ini antara lain :

a. Wawancara

Pengumpulan data dilakukan melalui proses wawancara kepada pihak yang berhubungan langsung dengan proses penerimaan remunerasi dosen di Universitas Islam Negeri Sumatera Medan yaitu Lembaga Penjaminan Mutu (LPM), Satuan Pengawas Intern (SPI) serta Pusat Teknologi Informasi dan Pangkalan Data (PUSTIPADA)

b. Studi Pustaka

Studi pustaka dilakukan untuk mendapatkan teori yang mendukung penelitian yang sedang dilakukan. Adapun hal yang dapat dipelajari dari studi pustaka yaitu definisi dari Rule Based Reasoning dan cara penggunaan dalam sistem. Studi pustaka didapatkan melalui buku, jurnal, artikel, maupun berbagai referensi yang diperbolehkan untuk digunakan dalam menyelesaikan penelitian ini. Studi ini juga difokuskan pada Rubrik Beban Kerja Dosen yang telah dibukukan oleh Universitas Islam Negeri Sumatera Utara Medan. 


\subsection{Metode Rule Based Reasoning}

Rule Based Reasoning (RBR) merupakan aturan-aturan logis dimana setiap aturannya didapat dari studi literatur dan informasi dari ahli tanpa melihat kasus yang dihadapi. Selain itu ada beberapa cara alternatif untuk memperoleh aturan tersebut menggunakan metode pembelajaran mesin berdasarkan data empiris yang ada. Satu aturan direpresentasikan dengan: IF THEN, dimana setiap kondisi-kondisi dari aturan ke aturan yang lainnya terhubung satu dengan yang lain melalui penghubung logika seperti penghubung dan, atau, negasi, serta penghubung lainnya membentuk sebuah fungsi logis [1].

Rule Based Expert System adalah advanced computer program yang mencoba untuk meniru kemampuan manusia dalam membuat keputusan dan pemecahan masalah [2]. Ide awal pengembangan metode Rule Based adalah dengan membentuk sekumpulan rules (aturan) pada basis pengetahuan. Kemudian untuk memperoleh informasi baru, digunakan inference engine [3]. Bentuk dari penggunaan Rule Based adalah biasanya dengan menggunakan model IF - THEN, sehinggga dihasilkan aturan-aturan statis.

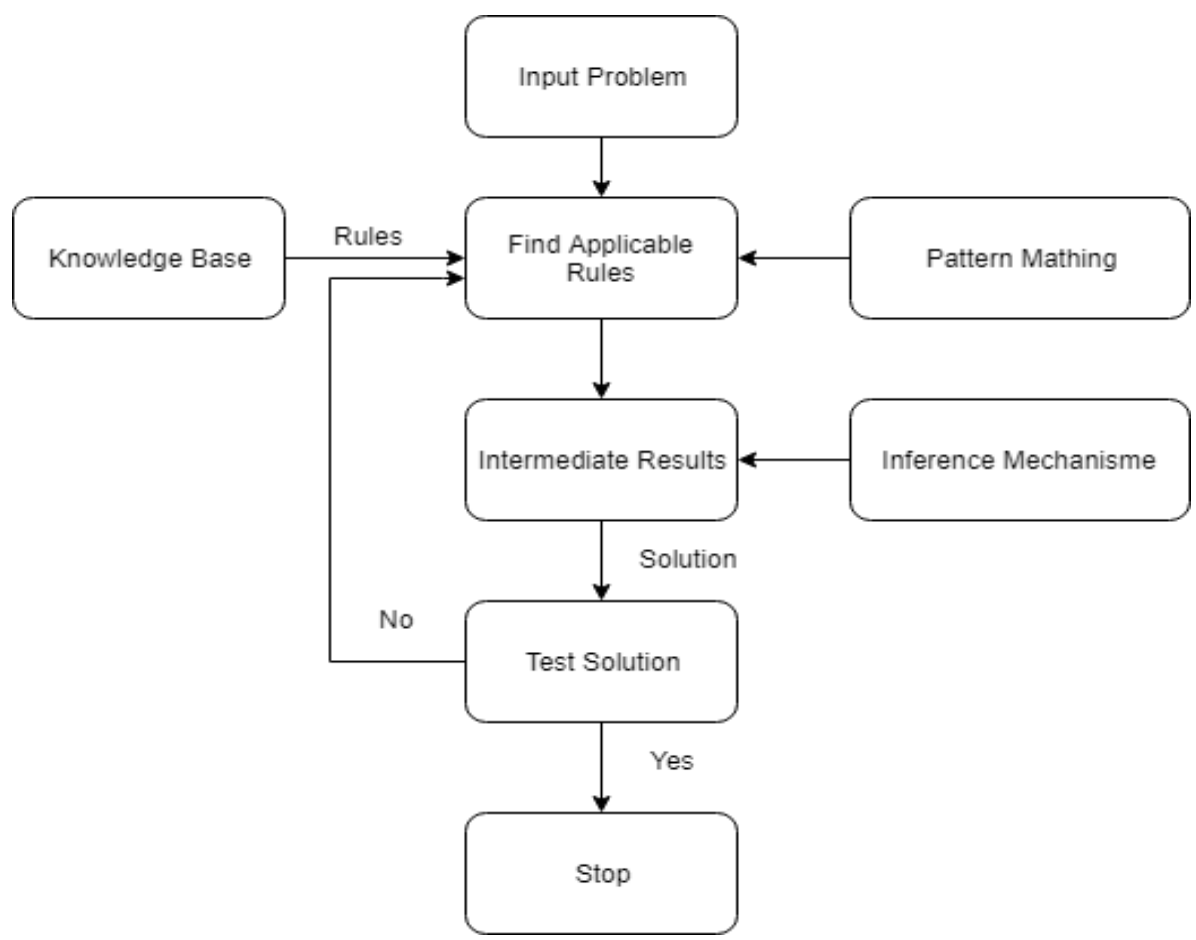

Gambar 1. Struktur Solusi RBR

\subsection{Remunerasi}

Remunerasi Jika diartikan secara harafiah yaitu "penggajian" atau "payment". Bisa juga dikatakan sebagai imbalan uang ataupun yang lainnya, yang telah ditetapkan oleh peraturan tertentu sebagai imbalan pekerjaan yang sifatnya rutin. Jadi yang dimaksud remunerasi adalah balas jasa atau imbalan yang diberikan oleh perusahaan kepada tenaga kerjanya sebagai dari prestasinya karena telah 
membantu perusahaan dalam mencapai tujuan. Atau remunerasi yaitu suatu imbalan yang diberikan kantor atau perusahaan kepada tenaga kerjanya karena telah berjasa kepada kantor atau perusahaan dalam membatu mencapai tujuannya. Keberadaan tenaga kerja yang berprestasi memberikan isyarat bahwa keberadaannya dalam organisasi suatu perusahaan tidak dapat diabaikan begitu saja, sebab tenaga kerja yang berprestasi telah membantu perusahaan dalam mencapai target atau tujuannya, tentunya untuk kelangsungan hidup perusahaan. Tingkat besarnya remunerasi pada setiap perusahaan tentunya berbeda-beda. Karena disebabkan oleh berbagai macam faktor yang dapat mempengaruhinya, diantaranya kemampuan perusahaan, keterampilan atau skill tenaga kerja, peranan perusahaan, serikat buruh, resiko pekerjaan, gaya hidup, lamanya bekerja, campur tangan dari pemerintah, permintaan dan penawaran tenaga kerja. Sistem remunerasi berbeda-beda pada setiap perusahaan, hal ini tergantung juga kepada sistem kerja yang dipakai oleh perusahaan. [4]

\subsection{Tujuan Remunerasi}

Supaya lebih jelas berikut di bawah ini beberapa tujuan dari remunerasi, yang diantaranya [4]:

a. Mendorong terciptanya SDM (Sumber Daya Manusia) yang berkualitas.

b. Untuk memelihara Sumber Daya Manusia yang produktif, supaya tidak berpindah ke perusahaan lain dan membentuk perilaku yang beorientasi pada layanan serta untuk mengurangi maupun mencegah tindakan KKN (Korupsi Kolusi \& Nepostime).

c. Dengan sistem remunasi dapat tercipta persingan yang positif antara tenaga kerja pada suatu perusahaan. Karena dengan sistem ini akan terlihat mana saja tenaga kerja yang rajin, yang memiliki kemauan untuk belajar dan yang tidak. Jadi tenaga kerja akan memiliki motivasi untuk terus mengembangkan dirinya.

d. Untuk menghasilkan pendapatan atau keuntungan yang sebesar-besarnya bagi suatu perusahaan dengan memanfaatkan modal seefektif dan seefesien mungkin.

e. Untuk menciptakan dan meningkatkan kesejahteraan tenaga kerja, dengan begitu maka akan berdampak pada peningkatan produktivitas dalam bekerja.

f. Untuk menciptakan tata kelola perusahaan yang baik dan juga bersih.

\subsection{Unsur-Unsur Remunerasi}

Ada 2 (dua) unsur dalam remunerasi, diantaranya unsur kompensasi dan bonus/komisi [4].

a. Kompensasi yaitu semua hal yang diterima oleh tenaga kerja/pegawai baik itu yang bentuknya fisik maupun yang non-fisik. Hal ini dapat dihitung dan dapat diberikan kepada tenaga kerja dan biasanya konpensasi tidak dikenakan pajak.

b. Bonus/komisi yaitu imbalan yang diberikan kepada tenaga kerja/pegawai dengan perhitungan presentase, misalnya keuntungan atas produk yang telah dijualnya. Pemberian komisi biasanya digabung dengan pemberian gaji tapi

Optimalisasi Penerimaan Remunerasi Dosen dengan Metode Rule Base Reasoning (Samsudin)| 228 
terkadang ada juga perusahaan yang hanya menerapkan sistem komisi saja tanpa pemberian gaji.

\subsection{Sistem Pakar}

Sistem pakar adalah suatu sistem yang berusaha mengadopsi pengetahuan manusia ke dalam komputer agar komputer dapat menyelesaikan masalah seperti yang biasa dilakukan oleh para pakar. Sistem pakar menurut [3]. Disusun oleh dua bagian utama, yaitu lingkungan pengembangan (development environment) dan lingkungan konsultasi (consultation environment). Lingkungan pengembangan sistem pakar digunakan untuk memasukkan pengetahuan pakar ke dalam lingkungan sistem pakar, sedangkan lingkungan konsultasi digunakan oleh pengguna yang bukan pakar guna memperoleh pengetahuan pakar.

Menurut [5], Pengembangan sistem pakar sendiri akan dikembangkan lebih lanjut dengan alasan, sebagai berikut:

a. Pengetahuan dari seorang pakar mahal harganya.

b. Seorang pakar suatu ketika akan pensiun dari pekerjaanya bahkan bisa meninggal dunia sehingga pengetahuan dari pakar akan hilang dan tidak dapat diturunkan ke pakar yang lebih junior.

c. Secara otomatis dapat mengerjakan tugas-tugas rutin yang membutuhkan seorang pakar.

d. Kepakaran juga dibutuhkan setiap waktu dan diberbagai lokasi bahkan pada lokasi yang kurang atau tidak mendukung.

\subsection{Komponen Sistem Pakar}

Menurut [6]. Komponen utama pada sistem pakar meliputi:

a. Basis Pengetahuan (KnowledgeBase)

Basis pengetahuan merupakan inti dari suatu sistem pakar, yaitu berupa representasi pengetahuan dari pakar.

b. Mesin Inferensi (Inference Engine)

Mesin inferensi berperan sebagai otak dari sistem pakar. Di dalam mesin inferensi terjadi proses untuk memanipulasi dan mengarahkan kaidah, model, dan fakta yang disimpan dalam basis pengetahuan dalam rangka mencapai solusi atau kesimpulan. Terdapat tiga teknik pengendalian yang sering digunakan, yaitu forward chaining, backward chaining, dan gabungan dari kedua tehnik pengendalian tersebut.

c. Basis Data (DataBase)

Basis data terdiri atas semua fakta yang diperlukan, di mana fakta-fakta tersebut digunakan untuk memenuhi kondisi dari kaidah-kaidah dalam sistem.

\section{HASIL DAN PEMBAHASAN}

\subsection{Arsitektur Sistem}

Untuk memahami konsep dari sistem penerimaan remunerasi dosen yang akan dibangun, maka pada gambar 1 berikut ini digambarkan arsitektur sistem. 


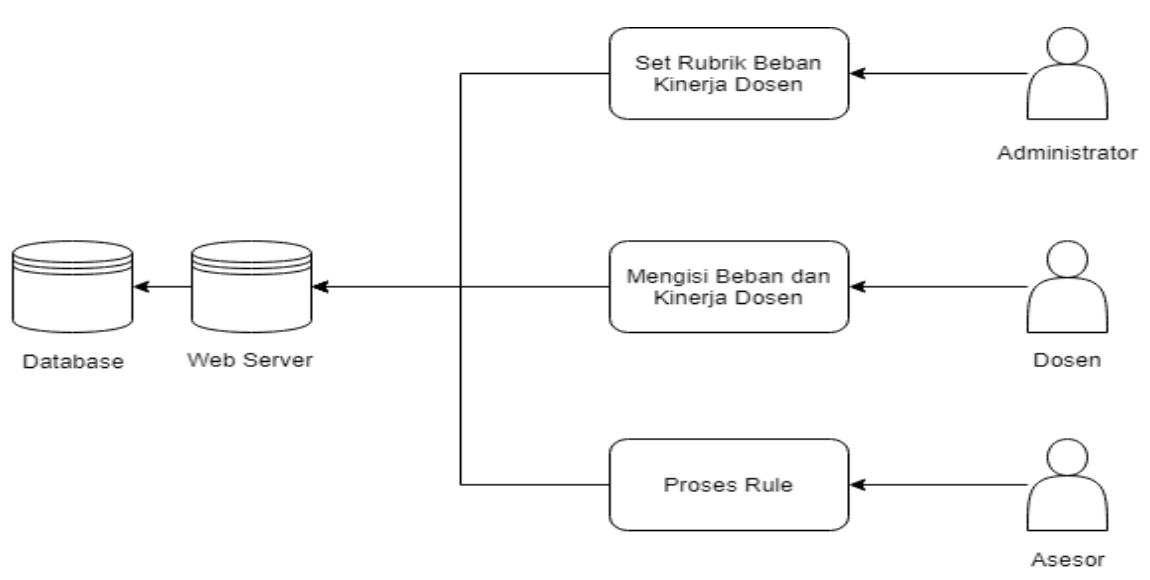

Gambar 2. Arsitektur Sistem

\subsection{Perancangan Database}

Untuk mengimplementasikan metode ini kita memerlukan beberapa tabel untuk menyimpan Pengetahun yang digunakan dalam pengambilan keputusan tersebut, berikut ini tabel penting dalam mendukung metode ini.

a. Tabel Beban

Tabel beban menyimpan data beban kerja yang diwajibkan untuk semua dosen. Masing-masing data beban diberikan kode yang diperlukan dalan metode Rule Base Reasoning. Adapun tabel beban terlihat pada tabel 1 berikut ini:

Tabel 1. Beban

\begin{tabular}{cl}
\hline Kode & Keterangan \\
\hline B1 & Pendidikan \\
B2 & Penelitian \\
B3 & Pengabdian \\
B4 & Penunjang \\
\hline
\end{tabular}

b. Tabel Kategori

Tabel kategori untuk menyimpan kategori kinerja yang dinyatakan termasuk dalam lingkup kinerja yang dibayarkan pada remunerasi. Masing-masing data kategori diberikan kode yang diperlukan dalan metode Rule Base Reasoning Adapun tabel kategori seperti yang terlihat pada tabel 2 berikut ini:

Tabel 2. Kategori

\begin{tabular}{cl}
\hline Kode & \multicolumn{1}{c}{ Kategori } \\
\hline K1 & Kuliah tingkat S0-S1 \\
K2 & Kuliah tingkat S2-S3 \\
K3 & Mengembangkan Bahan Kuliah \\
K4 & Bimbingan Praktikum/Magang terhadap setiap kelompok
\end{tabular}

Optimalisasi Penerimaan Remunerasi Dosen dengan Metode Rule Base Reasoning (Samsudin)| 230 


\begin{tabular}{|c|c|}
\hline Kode & Kategori \\
\hline K5 & $\begin{array}{l}\text { Bimbingan kuliah kerja yang terprogram terhadap setiap } \\
\text { kelompok PKL/PPL/KKN }\end{array}$ \\
\hline K6 & $\begin{array}{l}\text { Seminar mahasiswa berkelompok, terstruktur dan terjadwal } \\
\text { disertai bimbingan oleh dosen, bukan sebagai bagian dari } \\
\text { kuliah/praktikum. Yang dimaksud adalah: seminar proposal } \\
\text { dan Mata Kuliah seminar, seminar hasil penelitian hibah } \\
\text { mahasiswa, seminar Tugas Akhir Mahasiswa. }\end{array}$ \\
\hline K7 & $\begin{array}{l}\text { Membaca/ Membimbing Proposal/Tugas Akhir, 1) S1 } \\
\text { (Skripsi), 2) S2 (Tesis), 3) Membaca/ Membimbing Proposal } \\
\text { Tugas Akhir S3 (Disertasi) }\end{array}$ \\
\hline K8 & $\begin{array}{l}\text { Menguji Seminar Proposal: 1) S1 (Skripsi), 2) S2 (Tesis), 3) } \\
\text { S3 (Disertasi) }\end{array}$ \\
\hline K9 & Seminar Hasil Disertasi \\
\hline K10 & $\begin{array}{l}\text { Bimbingan Tugas Akhir Mahasiswa: 1) S1 (Skripsi), 2) S2 } \\
\text { (Tesis), 3) S3 (Disertasi) Dosen Pembimbing utama dan } \\
\text { pembimbing penyerta dinilai sama }\end{array}$ \\
\hline
\end{tabular}

c. Tabel Kinerja

Tabel kategori untuk menyimpan kategori kinerja yang dinyatakan termasuk dalam lingkup kinerja yang dibayarkan pada remunerasi. Masing-masing data kategori diberikan kode yang diperlukan dalan metode Rule Base Reasoning Adapun tabel kategori seperti yang terlihat pada tabel 3 berikut ini:

Tabel 3. Kinerja

\begin{tabular}{|c|c|c|c|}
\hline Kode & Kegiatan & Bukti & SKS $\mathrm{x}$ \\
\hline \multirow[t]{2}{*}{ R1 } & Mengajar 1-40 & -SK Pimpinan & 1 \\
\hline & $\begin{array}{l}\text { Mahasiswa selama } 1 \\
\text { semester }\end{array}$ & $\begin{array}{l}\text { - BAP } \\
\text { - Presensi } \\
\text { - Nilai }\end{array}$ & \\
\hline \multirow[t]{2}{*}{ R2 } & Mengajar 41-80 & -SK Pimpinan & 1,5 \\
\hline & $\begin{array}{l}\text { Mahasiswa selama } 1 \\
\text { semester }\end{array}$ & $\begin{array}{l}\text { - BAP } \\
\text { - Presensi } \\
\text { - Nilai }\end{array}$ & \\
\hline \multirow[t]{2}{*}{ R3 } & Mengajar 81-120 & -SK Pimpinan & 2 \\
\hline & $\begin{array}{l}\text { Mahasiswa selama } 1 \\
\text { semester }\end{array}$ & $\begin{array}{l}\text { - BAP } \\
\text { - Presensi } \\
\text { - Nilai }\end{array}$ & \\
\hline \multirow[t]{4}{*}{$\mathrm{R} 4$} & Mengajar 1-15 & -SK Pimpinan & 1 \\
\hline & Mahasiswa selama 1 & $\bullet \mathrm{BAP}$ & \\
\hline & semester & - Presensi & \\
\hline & & • Nilai & \\
\hline
\end{tabular}




\begin{tabular}{|c|c|c|c|}
\hline Kode & Kegiatan & Bukti & SKS x \\
\hline R5 & $\begin{array}{l}\text { Mengajar 16-30 } \\
\text { Mahasiswa selama } 1 \\
\text { semester }\end{array}$ & $\begin{array}{l}\text { - SK Pimpinan } \\
\text { - BAP } \\
\text { - Presensi } \\
\text { - Nilai }\end{array}$ & 1,5 \\
\hline R6 & $\begin{array}{l}\text { Menulis } 1 \text { judul buku/ } \\
\text { bahan ajar utuh yang } \\
\text { relevan dengan } \\
\text { keahlian/SK Dosen }\end{array}$ & $\begin{array}{l}\text { - SK/ SuratTugas } \\
\text { - Proses } \\
\text { - Penulisan } \\
\text { (DrafBuku dan } \\
\text { Surat Keterangan } \\
\text { Kerjasama/ } \\
\text { Kontrak } \\
\text { Penerbit) } \\
\text { - Buku/Diktat/Mod } \\
\text { ul Jadi (Cover, } \\
\text { Halaman } \\
\text { Deskripsi, } \\
\text { - Halaman ISBN [ } \\
\text { khusus buku } \\
\text { ajar] danDaftar } \\
\text { isi)atauLink on- } \\
\text { line (repository } \\
\text { UINSU, } \\
\text { academia.edu, } \\
\text { google scholar, } \\
\text { researchgate) }\end{array}$ & 5 \\
\hline R7 & $\begin{array}{l}\text { Diktat } \\
\text { /Modul/Petunjuk } \\
\text { Praktikum/Model/Alat } \\
\text { Bantu/ Audio Visual/ } \\
\text { Naskah Tutorial }\end{array}$ & $\begin{array}{l}\text { - Petunjuk } \\
\text { Praktikum, Model, } \\
\text { Alat Bantu, Audio } \\
\text { Visual, Naskah } \\
\text { Tutoria dan Surat } \\
\text { Keterangan dari } \\
\text { Pimpinan } \\
\text { - Link on-line } \\
\text { (repository UINSU, } \\
\text { academia.edu, } \\
\text { google scholar, } \\
\text { researchgate). }\end{array}$ & 2 \\
\hline R8 & $\begin{array}{l}\text { Bimbingan } 1-25 \text { orang } \\
\text { mahasiswa selama } 1 \\
\text { semester, } 2 \text { jam } \\
\text { perminggu (minimal } \\
12 \text { kali tatap muka) }\end{array}$ & $\begin{array}{l}\text { - SK/ Surat Tugas } \\
\text { dari Pimpinan } \\
\text { - Presensi } \\
\text { Mahasiswa } \\
\text { - BAP/Berita Acara } \\
\text { Praktikum }\end{array}$ & 1 \\
\hline
\end{tabular}




\begin{tabular}{|c|c|c|c|}
\hline Kode & Kegiatan & Bukti & SKS $\mathrm{x}$ \\
\hline R9 & $\begin{array}{l}\text { 1-25 orang mahasiswa, } \\
\text { kegiatan yang setara } \\
\text { dengan } 50 \text { jam kerja } \\
\text { per semester sama } \\
\text { dengan } 1 \text { sks } 6 \text { hari } \\
\text { termasuk untuk } \\
\text { persiapan, } \\
\text { pelaksanaan dan } \\
\text { pelaporan }\end{array}$ & $\begin{array}{l}\text { - Nilai praktikum } \\
\text { - SK/ Surat Tugas } \\
\text { dari pimpinan. } \\
\text { - Presensi } \\
\text { Mahasiswa. } \\
\text { - Nilai PKL/ } \\
\text { PPL/KKN. }\end{array}$ & 1 \\
\hline $\mathrm{R} 10$ & $\begin{array}{l}\text { Bimbingan Tugas } \\
\text { Akhir Mahasiswa: 1) } \\
\text { S1 (Skripsi), 2) S2 } \\
\text { (Tesis), 3) S3 } \\
\text { (Disertasi) Dosen } \\
\text { Pembimbing utama } \\
\text { dan pembimbing } \\
\text { penyerta dinilai sama }\end{array}$ & $\begin{array}{l}\text { - SK/ Surat Tugas } \\
\text { dari pimpinan. } \\
\text { - Bukti } \\
\text { Pembimbingan. }\end{array}$ & 1 \\
\hline
\end{tabular}

d. Tabel Knowledge

Tabel knowledge untuk menyimpan rule knowledge yang merupakan bagian penting dari metode Rule Base Reasoning. Adapun tabel knowledge seperti yang terlihat pada tabel 4 berikut ini:

Tabel 4. Knowledge

\begin{tabular}{cccc}
\hline No & Kategori & Kinerja & Beban \\
\hline 1 & K1 & R1 & B1 \\
2 & K1 & R2 & B1 \\
3 & K1 & R3 & B1 \\
4 & K2 & R4 & B1 \\
5 & K2 & R5 & B1 \\
6 & K3 & R6 & B1 \\
7 & K3 & R7 & B1 \\
8 & K4 & R8 & B1 \\
9 & K4 & R9 & B1 \\
10 & K10 & R10 & B1 \\
\hline
\end{tabular}

IF $($ Kategori $=$ K1) AND $($ Kinerja $=$ R1 $)$ THEN Beben = B1

Seorang dosen mengajar matakuliah pada jenjang S1 Program Studi Sistem Informasi pada semester Genap 2018/2019 pada kelas yang mempunyai jumlah 40 orang mahasiswa. Pada proses perkuliahan dosen tersebut juga membuat Modul Ajar. Selain itu, dosen tersebut juga mempunyai mahasiswa bimbingan skripsi sebanyak 4 orang. Berapakan remunerasi yang didapat dari kasus singkat tersebut? 
a. Mengajar Matakuliah Tingkat S1 (K1)

b. Mengajar 1-40 Orang Mahasiswa (R1)

IF K1 AND R1 THEN B1 = 1 sks

a. Mengembangkan Bahan Kuliah (K2)

b. Membuat Modul Ajar (R7)

IF K2 AND R7 THEN B1 = 2 sks

a. Bimbingan Tugas Akhir (K10)

b. Bimbingan Skripsi (R10)

IF K10 ANF R10 THEN B1 = 1 sks

Total sks $=4$ sks

Remunerasi $=$ Nominal Remunerasi setiap SKS (misal 1.000.000/sks)

Total Remunerasi 4 x 1.000.000 $=4.000 .000$

\subsection{Use Case Diagram}

Use Case merupakan perilaku software aplikasi dimana proses tersebut menggambarkan suatu sistem, sehingga yang menggunakan sistem akan mudah mengerti mengenai kegunaan sistem yang dibangun [7]. Use Case Diagram adalah gambaran (graphical) dari beberapa actor, Use Case, dan interaksi diantaranya yang memperkenalkan suatu sistem. Use Case Diagram menggambarkan siapa saja aktor yang melakukan prosedur dalam sistem serta fungsi-fungsi (proses) yang terlibat dalam transformasi pada sistem tersebut.

Adapun use case diagram yang diusulkan pada penelitian ini adalah sebagai berikut :

a. Actor

Actor yang terdapat pada sistem yang diusulkan ini adalah :

1) Administrator, actor ini bisa melakukan pengolahan data rubrik, yaitu penambahan dan perubahan data rubrik. Administrator juga bisa menambahkan dan melakukan perubahan terhadap data dosen.

2) Dosen, actor ini bisa melakukan penambahan dan perubahan serta menghapus data beban dan kinerja dosen setiap semester.

3) Asesor, actor ini hanya bisa melakukan proses

\section{b. Use Case Requirement}

Setelah mengidentifikasi actor, tahap selanjutnya adalah menentukan kebutuhan fungsi use case yang dibutuhkan oleh sistem dalam interaksinya dengan actor-actor tersebut.

\subsection{Class Diagram}

Class diagram menampilkan eksistensi atau keberadaan dari class-class dan hubungan (relationship) dalam desain logikal dari sebuah sistem. Semua proses yang dilakukan oleh aktor terhadap aplikasi akan didefinisikan dengan menggunakan class diagram. Class diagram merupakan diagram yang akan 
memperlihatkan dan menjelaskan tabel-tabel pada database dan relasi antar tabel yang akan digunakan didalam sistem ini.

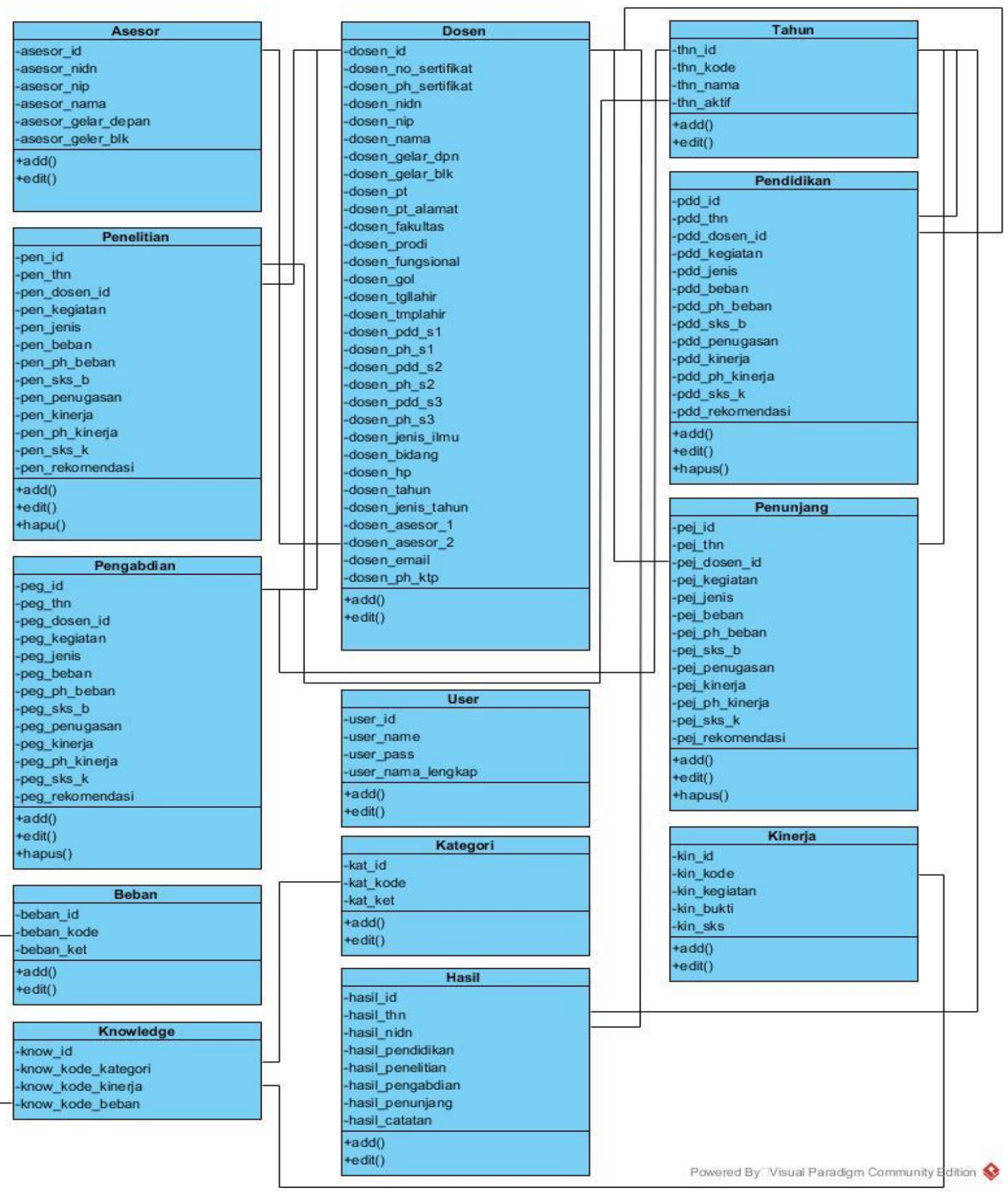

Gambar 3. Class Diagram

Optimalisasi Penerimaan Remunerasi Dosen dengan Metode Rule Base Reasoning (Samsudin) | 235 


\subsection{Activity Diagram}

Activity diagram merupakan diagram untuk menggambarkan logika prosedur, proses dan jalur kerja yang terjadi dalam sistem yang akan dirancang [8]. Berikut activity diagram dari sistem informasi yang dirancang.

a. Activity Diagram pengolahan Asesor

Pengolahan data Asesor dilakukan oleh administrator, dimana administrator bisa melakukan penambahan data asesor yang dilanjutkan dengan pemeriksaan kelengkapan data oleh sistem terhadap data yang ditambahkan. Berikut gambar Activity Diagram pengolahan data Asesor.

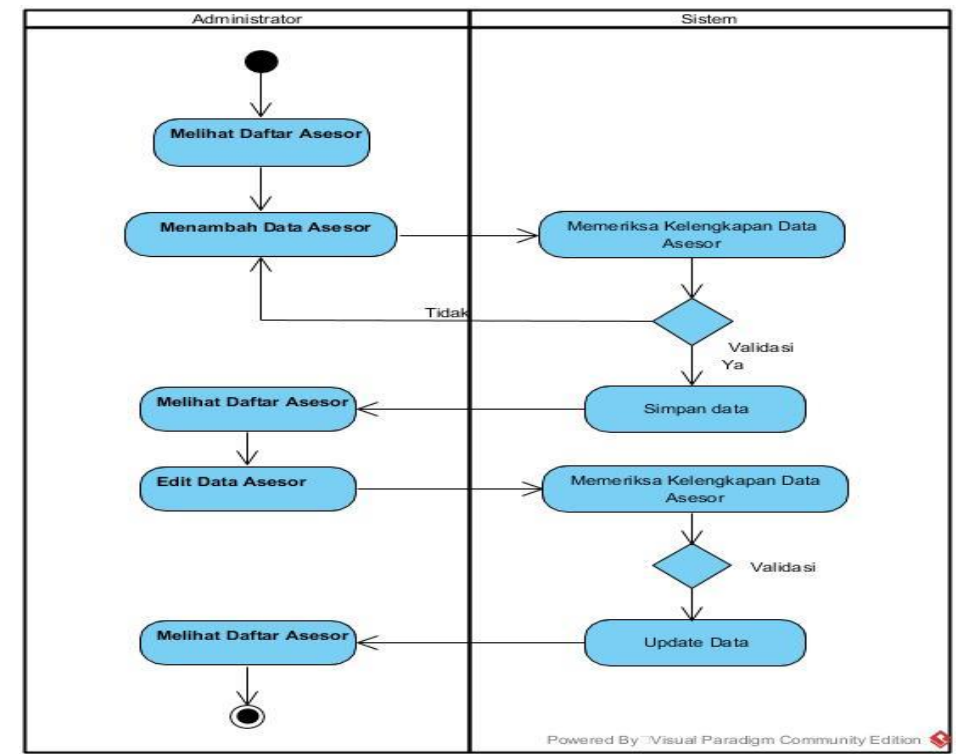

Gambar 4. Activity Diagram pengolahan data Asesor

b. Activity Diagram pengolahan Dosen

Pengolahan data dosen dilakukan oleh masing-masing Dosen, dimana Dosen bisa melakukan penambahan data setiap tahun akademik yang dilanjutkan dengan pemeriksaan kelengkapan data oleh sistem terhadap data yang ditambahkan apabila diperlukan perubahan data, maka dosen juga bisa melakukan perubahan yang dilanjutkan dengan validasi kelengkapan data oleh sistem. Berikut gambar Activity Diagram pengolahan data Dosen. 


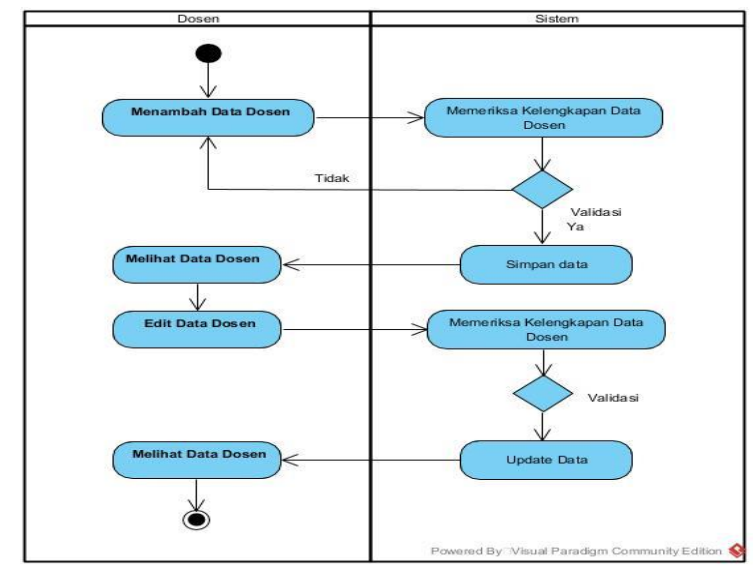

Gambar 5. Activity Diagram pengolahan data Dosen

\subsection{Pengujian Sistem}

Setelah dilakukan perancangan sistem maka tahap akhir adalah pengujian sistem apakah metode yang digunakan bisa berjalan dengan semestinya sehingga optimalisasi penerimaan remunerasi dosen bisa terwujud. Berikut tampilan hasil akhir sistem yang dirancang.

\section{a. Data User}

Menu user berfungsi untuk menampilkan data pengguna sistem. Pada menu ini bisa digunakan untuk melakukan perubahan password atau pembuatan akun pengguna baru.

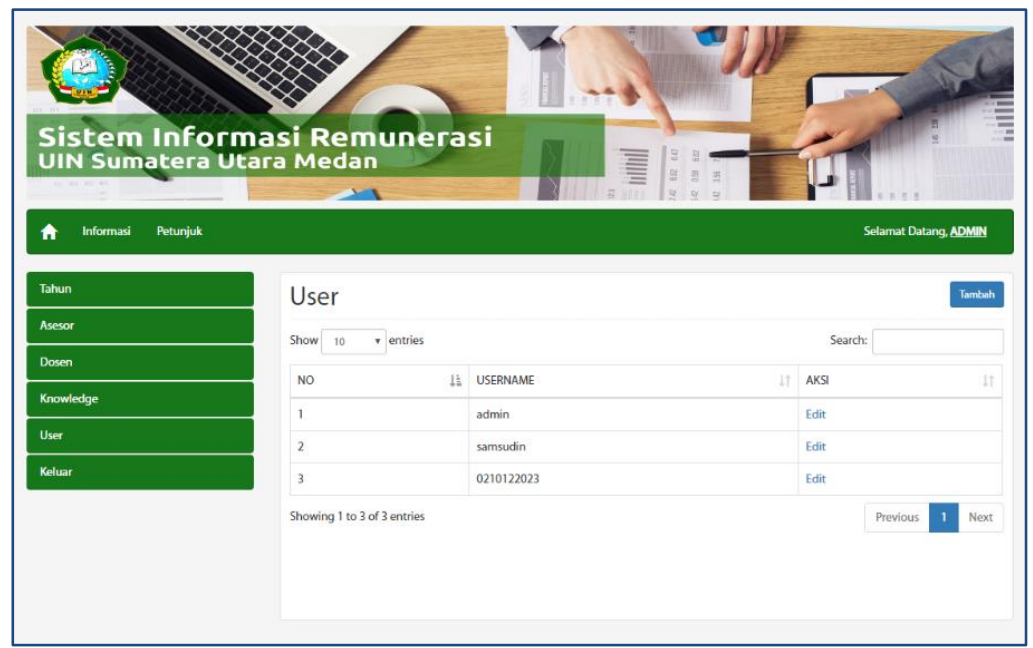

Gambar 6. Halaman Menu User 
b. Data Asesor

Menu asesor berfungsi untuk menyimpan data asesor yang melakukan penilaian terhadap Beban Kerja Dosen.

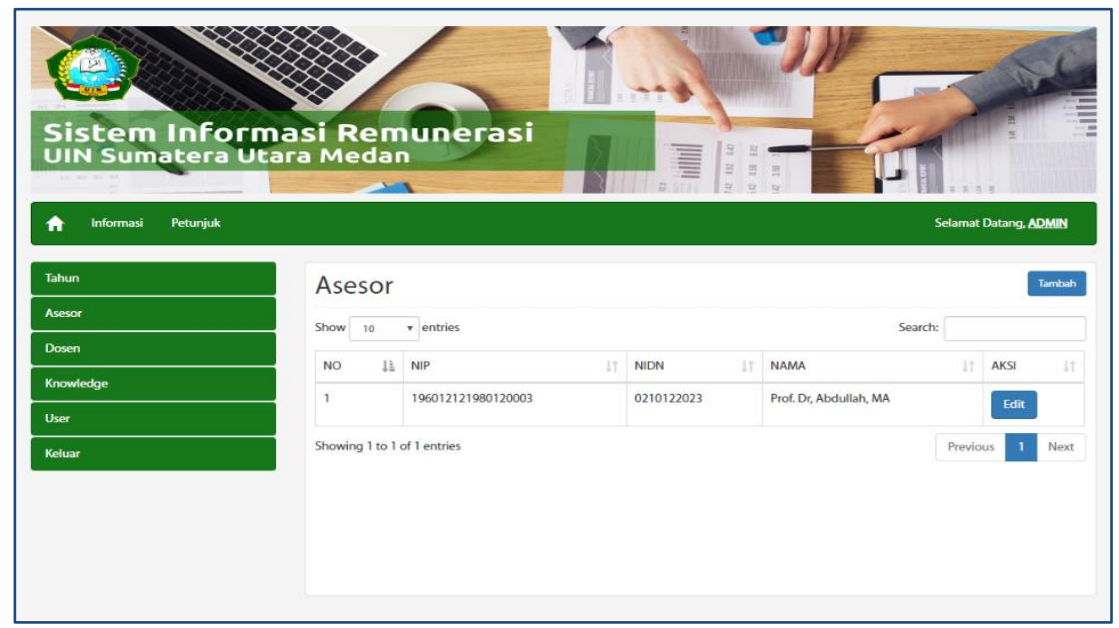

Gambar 7. Halaman Asesor

c. Data Dosen

Menu dosen berfungsi untuk menampikan data dosen yang ada dalam sistem.

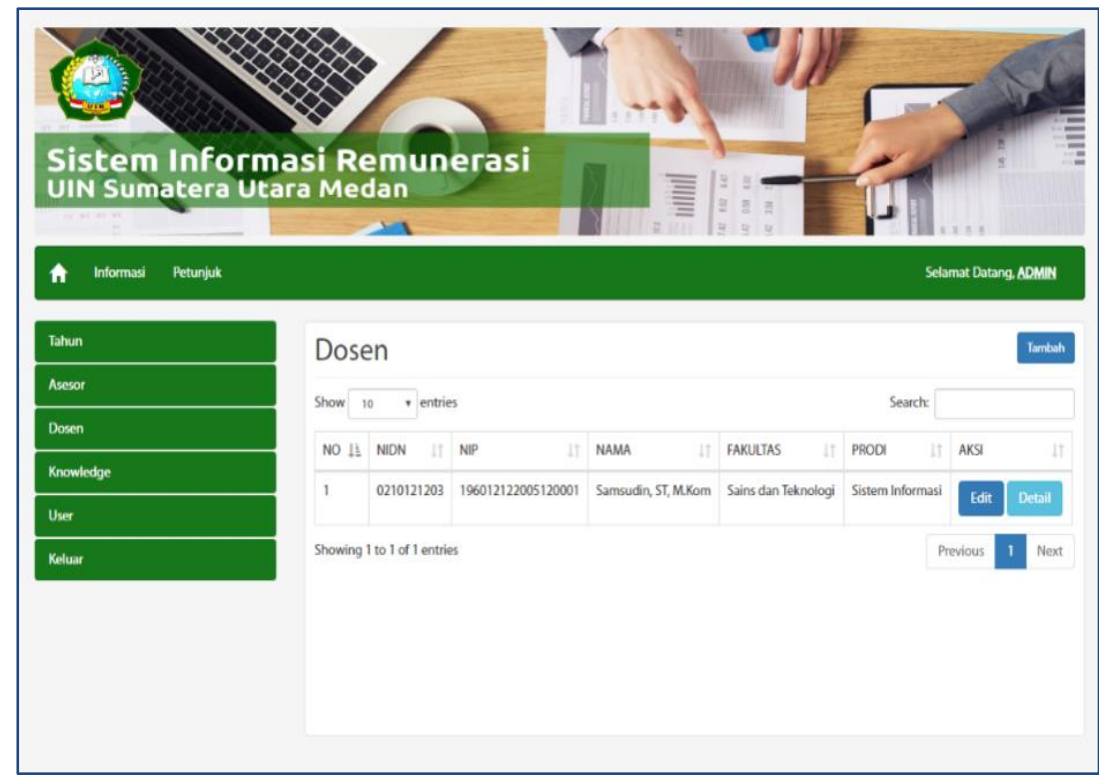

Gambar 8. Halaman Dosen

d. Data Diri Dosen

Menu data diri dapat ditemukan pada akun dosen. Menu ini berfungsi untuk menyimpan data dosen yang akan melakukan penyerahan data beban kerja dosen. 


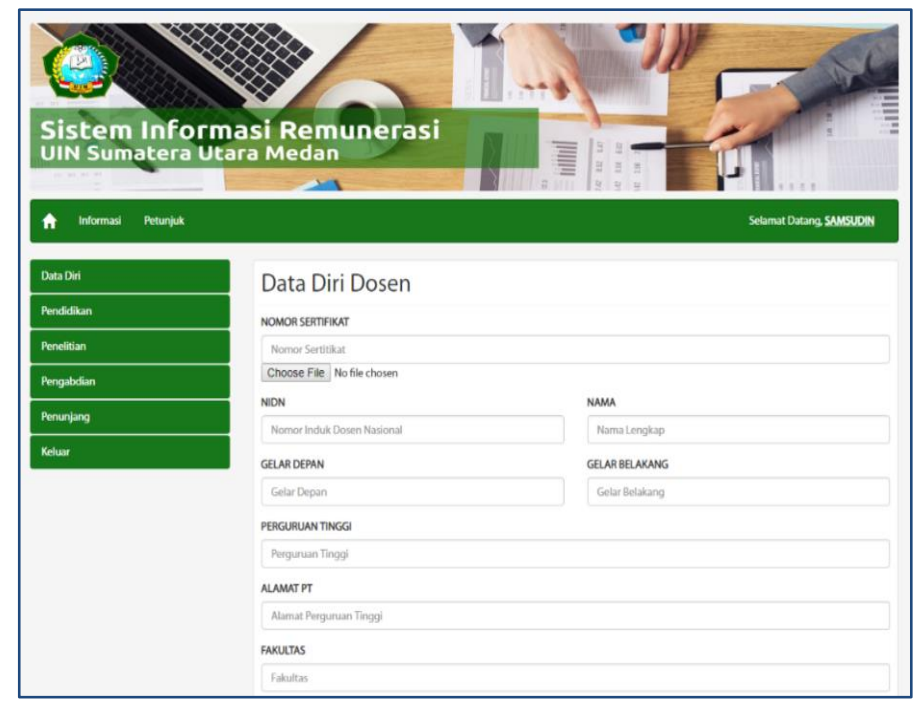

Gambar 9. Halaman Menu Data Diri Dosen

e. Data Penilaian

Menu penilaian dapat ditemukan pada akun asesor, menu ini berfungsi untuk melakukan penilaian terhadap beben kerja dosen yang telah di-input oleh masing-masing dosen.

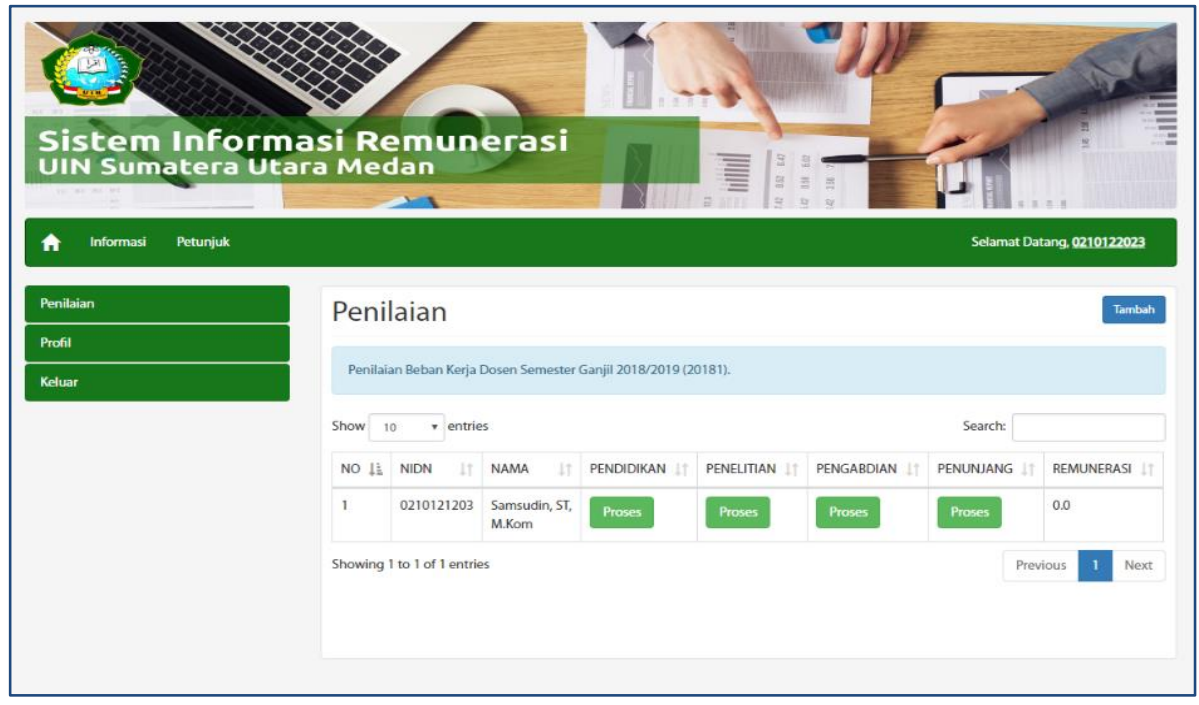

Gambar 10. Halaman Menu Penilaian Dosen

\section{SIMPULAN}

Kesimpulan dari pembuatan makalah ini adalah:

a. Perancangan sistem penentuan penerimaan remunerasi dosen UIN Sumatera Utara Medan menggunakan Metode Rule Base Reasoning efektif untuk membantu kinerja Asesor dalam melakukan penilaian.

b. Konsep Object Oriented dan sistem berbasis web yang dibangun sangat membantu sistem yang lebih reusable dan bisa diakses secara realtime, tanpa terbatas waktu dan tempat. 


\section{DAFTAR PUSTAKA}

[1] M. A. Irfandi, A. Romadhony, S. Saadah, F. T. Informatika, and U. Telkom, "Indonesia Symposium On Computing 2015 MENGGUNAKAN METODE HYBRID CASE-BASED DAN RULE-BASED REASONING,” pp. 219-225, 2015.

[2] L. Ceccaroni, "Integration of a rule-based expert system, a case-based reasoner and an ontological knowledge-base in the wastewater domain."

[3] E. Turban, Decision support and expert systems (4th ed.): management support systems. California : Prentice-Hall International Inc, 1995.

[4] S. N, "Pengertian Remunerasi Dan Tujuannya Singkat," http://www.pengertianku.net/2016/09/pengertian-remunerasi-dantujuannya.html, 2016. .

[5] M. Arhami, Konsep Dasar Sistem Pakar. Andi, Yogyakarta, 2004.

[6] S. Kusrini, Sistem Pakar Teori dan Aplikasi. Andi. Yogyakarta, 2006.

[7] M. Muslihudin, Analisis Dan Perancangan Sistem Informasi Menggunakan Model Terstruktur Dan UML. Andi, Yogyakarta, 2016.

[8] T. Sutabri, Analisis Sistem Informasi. Andi, Yogyakarta, 2014. 